\title{
A meta-analysis of responses of wheat yield formation to elevated ozone concentration
}

\author{
FENG ZhaoZhong ${ }^{1,2 \dagger}$, KOBAYASHI Kazuhiko ${ }^{2}$, WANG XiaoKe ${ }^{1}$ \& FENG ZongWei ${ }^{1}$ \\ ${ }^{1}$ State Key Laboratory of Urban and Regional Ecology, Research Center for Eco-Environmental Sciences, Chinese Academy of \\ Sciences, Beijing 100085; \\ ${ }^{2}$ Department of Global Agricultural Sciences, Graduate School of Agricultural and Life Sciences, The University of Tokyo, Tokyo \\ 113-8657, Japan
}

The meta-analysis method was applied to quantitatively investigate effects of the elevated ozone concentration $\left(\left[\mathrm{O}_{3}\right]\right)$ on chlorophyll concentration, gas exchange and yield components of wheat. There were 39 effective references through Web of Science (ISI, USA) and Chinese journal full-text database (CNKI, China). The results of meta-analysis indicated that elevated $\left[\mathrm{O}_{3}\right]$ decreased grain yield, grain weight, grain number per ear, ear number per plant and harvest index by $26 \%, 18 \%, 11 \%, 5 \%$ and $11 \%$, respectively, relative to ambient air. The decrease in leaf physiological characters was much greater than that in yield when wheat was expose to elevated $\left[\mathrm{O}_{3}\right]$, while light-saturated photosynthetic rate (Asat), stomatal conductance (Gs) and chlorophyll content (Chl) decreased by $40 \%, 31 \%$, and $46 \%$, respectively. The responses to elevated $\left[\mathrm{O}_{3}\right]$ between spring wheat and winter wheat were similar. Most of the variables showed a linear decrease trend with an increase of $\left[\mathrm{O}_{3}\right]$. The most significant decrease for Asat, $\mathrm{Gs}$ and $\mathrm{Chl}$ was found in grain filling stage. Elevated $\left[\mathrm{CO}_{2}\right]$ could significantly ameliorated or offset the detrimental effects caused by elevated $\left[\mathrm{O}_{3}\right]$.

meta-analysis, elevated $\left[\mathrm{CO}_{2}\right]$, wheat, ozone, gas exchange, yield

Surface ozone $\left(\mathrm{O}_{3}\right)$ was the most important phytotoxic gaseous pollutant to the terrestrial vegetation in many parts of the world ${ }^{[1]}$. Since 1960 s, elevated ambient $\mathrm{O}_{3}$ concentration $\left(\left[\mathrm{O}_{3}\right]\right)$ in industrialized countries was reported to reduce growth and yield of $\mathrm{C} 3 \mathrm{crops}^{[2,3]}$. In the past decades, tropospheric $\left[\mathrm{O}_{3}\right]$ increased rapidly as a result of overuse of fossil fuel and nitrogen fertilizer ${ }^{[4]}$. Nearly one-quarter of the earth's surface is currently at risk from elevated $\left[\mathrm{O}_{3}\right]$ in excess of $60 \mathrm{ppb}(1 \mathrm{ppb}=2 \times$ $10^{-9} \mathrm{~g} / \mathrm{L}$ ) during mid-summer, and $\left[\mathrm{O}_{3}\right]$ increased at a rate of $0.3 \%-2.0 \%$ annually $^{[5]}$. Models predicted that tropospheric $\left[\mathrm{O}_{3}\right]$ could rise $20 \%-25 \%$ by 2050 , and further increase $40 \%-60 \%$ by 2100 if the current emission trends continue ${ }^{[4]}$. In addition, due to long distance transport of $\mathrm{NO}_{x}$ and VOCs, $\left[\mathrm{O}_{3}\right]$ higher than the critical level to plants appeared frequently in agricultural, forest and remote rural areas ${ }^{[6]}$. Surface $\mathrm{O}_{3}$ has been currently assumed as one of the major environmental issues in some rural and urban regions ${ }^{[7,8]}$.

Entering into mesophyll through leaf stomata, $\mathrm{O}_{3}$ can directly react with the plasmalemma through ozonolysis, or it can be converted into reactive oxygen species, including hydrogen peroxide that alter cellular components and can lead to cell death and accelerated senescence ${ }^{[9]}$. At the whole plant level, chronic $\mathrm{O}_{3}$ exposure can lead to visible leaf injuries, e.g. chlorosis, brown lesions and necrosis in wheat, chlorosis, brown lesions and furring in rice ${ }^{[10]}$. Elevated $\left[\mathrm{O}_{3}\right]$ could also induce reductions in biomass and yield of most plants, although

Received July 1, 2008; accepted October 23, 2008 doi: 10.1007/s11434-008-0552-6

${ }^{\dagger}$ Corresponding author (email: zhzfeng201@163.com)

Supported by National Natural Science Foundation of China (Grant No. 30670387), Eco-Frontier Fellowship of the Ministry of Environment, Japan (Grant No. 07-C062-03) and Ministry of Science and Technology of People's Republic China with 973 Project (Grant No. 2002CB410803) 
the observed responses varied with species and exposure conditions $^{[3,7,11-13]}$. Wheat was one of the most sensitive species to $\mathrm{O}_{3}{ }^{[14,15]}$. Lower ambient $\left[\mathrm{O}_{3}\right]$ reduced the yield by $40 \%$ in winter wheat relative to carbon-filtered air ${ }^{[16]}$. However, there existed a large difference in the detrimental effects of $\mathrm{O}_{3}$. The variability was not only resulted from exposure dose (concentration $\times$ time) and genetic differences, but also $\mathrm{O}_{3}$ exposure duration and fumigation regimes. Pleijel et al. ${ }^{[17]}$ investigated fieldgrown spring wheat exposed to the same ozone dose, before anthesis or after onset of anthesis, and concluded that ozone exposure between anthesis and the end of grain filling is much more effective in decreasing the wheat grain yield than ozone exposure occurred before anthesis. Meyer et al. ${ }^{[18]}$ found that dynamic $\left[\mathrm{O}_{3}\right]$ fumigation regime $\left(\left[\mathrm{O}_{3}\right]\right.$ peak) induced larger yield loss than constant $\left[\mathrm{O}_{3}\right]$ exposure regime did under equal doseconditions.

To assess the effects of elevated $\left[\mathrm{O}_{3}\right]$ on growth and yield, it is indispensable to cover the interaction between rising $\left[\mathrm{O}_{3}\right]$ with other environmental factors, such as elevated $\left[\mathrm{CO}_{2}\right]$, drought and high temperature. Factors that influence stomatal conductance (Gs) can alter the flux of $\mathrm{O}_{3}$ into intercellular spaces of the leaf. Water stress or elevated $\left[\mathrm{CO}_{2}\right]$ is accompanied by decreased Gs, which in turn less ozone reaches the inner leaf tissues, thereby decreasing ozone injury to the leaves. On the other hand, higher humility or soil water content aggravated the detrimental effects of $\mathrm{O}_{3}$ due to increased stomatal opening ${ }^{[19,20]}$. It can be expected that large variability could occur between individual studies due to the complexity of factors. Therefore, it is necessary to combine various factors to reveal quantitatively the detrimental effects of elevated $\left[\mathrm{O}_{3}\right]$ on growth of crops and study what the mechanisms are.

Meta-analysis is a quantitative approach that estimates a mean relative response from individual studies to find general trend and differences. It developed rapidly since it was successfully introduced into the field of ecology and evolutionary biology at $1990 \mathrm{~s}^{[21-23]}$. In 1999, metaanalysis application in ecology was published in a special issue of Ecology, which systematically discussed case studies, development and problems on its use in ecology ${ }^{[22]}$. With the increasing concerns on global change issues, meta-analysis has been adopted in this field extensively, e.g. the responses of ecosystem to global warming, rising $\left[\mathrm{CO}_{2}\right]$ and elevated $\left[\mathrm{O}_{3}\right]$, the effects of land use and management on climate change ${ }^{[21-23]}$. Lei et al. ${ }^{[21]}$ described the principles, steps, advantages and disadvantages of meta-analysis and reviewed its application in the field of climate change. However, very few studies used the meta-analytic technique in the field of ecology in China ${ }^{[24,25]}$.

In this review, we integrated all the relevant individual studies and used meta-analytic procedures to quantitatively determine the mean effects of elevated $\left[\mathrm{O}_{3}\right]$ on photosynthesis and yield loss of wheat, relative to ambient $\left[\mathrm{O}_{3}\right]$. In addition, the sources of variations, such as wheat genotypes, fumigation duration, developmental stages and elevated $\left[\mathrm{CO}_{2}\right]$ were also discussed. The results will be crucial to forecast future food safety induced by global atmospheric and environmental changes.

\section{Materials and methods}

\subsection{Development of database}

A database of effects of $\mathrm{O}_{3}$ on wheat growth and yield loss was compiled by surveying the peer-reviewed literature with the Web of Science (ISI, USA) and Chinese Journal Full-Text Database (CNKI, China). Keyword searches were made for $\mathrm{O}_{3}$ and wheat, covering the period 1980 through 2007. To be included in this metaanalysis, articles and measurements have to meet the following criteria: (i) ambient and elevated $\left[\mathrm{O}_{3}\right]$ treatments were included in each study; (ii) ozone fumigation was more than ten days; (iii) only one paper was selected if the data were reported in another one; (iv) responses have been measured with respect to yield (Y) and its components, such as individual grain weight $(\mathrm{GW})$, grains per ear (GNE) and ears per plant (ENP), harvest index(HI), above-ground biomass (Bs), lightsaturated photosynthetic rate (Asat), stomatal conductance (Gs) and chlorophyll content (Chl). Based on these criteria, 39 articles were used for this meta-analysis. Meta-analytic methods require that individual observations be statistically independent. Parameter values were considered independent if they were made on different cultivars, $\left[\mathrm{O}_{3}\right]$, different dates of measurements and additional treatments in the same experiment, following previous meta-analyses ${ }^{[26]}$. The mean value $\left(X_{\mathrm{C}}\right.$ and $\left.X_{\mathrm{E}}\right)$, the standard deviations and the replication in ambient $\left[\mathrm{O}_{3}\right]$ (as control) and elevated $\left[\mathrm{O}_{3}\right]$ (as treatment) were recorded in a database, together with the categorical 
information. Data were recorded directly from tables and texts and digitized from figures using data extraction software (GRAFULA, Russia). To explain variations in the response of wheat to elevated $\left[\mathrm{O}_{3}\right], 5$ categories were included as follows: (i) mean $\left[\mathrm{O}_{3}\right](30-59$, $60-89,90-119$ and $\geqslant 120 \mathrm{ppb}$ ); (ii) wheat types (spring wheat versus winter wheat); (iii) developmental stages (seedling, booting-anthesis and grain filling); (iv) durations of leaf fumigation $(3-10,11-20$ and $>20 \mathrm{~d}$ ); (v) additional treatments (no additional treatments, combination of elevated $\left[\mathrm{O}_{3}\right]$ and elevated $\left[\mathrm{CO}_{2}\right]$ ).

\subsection{Meta analysis}

To estimate the treatment effects, the natural log of the response ratio $(r)$ was used as the metric for analysis, where $r$ is the ratio of variables in elevated $\left[\mathrm{O}_{3}\right]\left(X_{\mathrm{E}}\right)$ divided by variables in ambient $\left[\mathrm{O}_{3}\right]\left(X_{\mathrm{C}}\right)^{[19,26]}$. Mean response ratio was carried out following the techniques in Curtis and Wang ${ }^{[26]}$, using MetaWin 2.0 statistical software. The mixed-model approach (random effect) was used based on the assumption of random variation in responses among studies. The approach used here was similar to that of reported previously in a single spe$\operatorname{cies}^{[19,27]}$. Many studies did not report standard deviations or standard errors with replicate size, which would allow computation of sample variance. In this case, re-sampling was used to develop a variance of the effect size $^{[28]}$. An unweighted meta-analysis was performed with significance determined from $95 \%$ confidence intervals (CI), which were calculated using bootstrap methods ${ }^{[28]}$.

Relative to ambient $\left[\mathrm{O}_{3}\right]$, the percentage change of the variables at elevated $\left[\mathrm{O}_{3}\right]$ was expressed as $(r-1) \times$ $100 \%{ }^{[27]} . r=1$ indicated that plant responses are the same in $\mathrm{CF}$ and elevated $\left[\mathrm{O}_{3}\right]$ treatments, and therefore no percentage change $(0 \%)$. Negative percentage change $(r<1)$ indicates a decrease in the plant variable in response to elevated $\left[\mathrm{O}_{3}\right]$ and positive values indicate an increase. Response to $\mathrm{O}_{3}$ treatment is assumed to be significant if the $95 \%$ CI did not overlap zero and the difference between categorical variables was considered significant if the $95 \%$ CIs did not overlap ${ }^{[19,26]}$.

\section{Results and analysis}

\subsection{Overall effects of elevated $\left[\mathrm{O}_{3}\right]$ on photosynthesis and yield component in wheat}

From Figure 1, elevated $\left[\mathrm{O}_{3}\right]$ induced much larger det- rimental effects on physiological characteristics than that on yield. Relative to ambient $\left[\mathrm{O}_{3}\right]$, more than $30 \%$ decreases in physiological characteristics including Asat, Gs and Chl were found, when wheat was exposed to elevated $\left[\mathrm{O}_{3}\right]$. The largest decrease $(46 \%)$ was in $\mathrm{Chl}$ with the $95 \%$ CI of $39 \%-53 \%$. Elevated $\left[\mathrm{O}_{3}\right]$ decreased Asat by $40 \%$, which might be from a combination of decreases of $\mathrm{Chl}$ and Gs (31\%). Across all studies, mean $\left[\mathrm{O}_{3}\right]$ of $77 \mathrm{ppb}$ decreased grain yield by $26 \%$, relative to the average ambient $\left[\mathrm{O}_{3}\right]$ of $35 \mathrm{ppb}$. The yield loss mainly resulted from a combination of lower GW $(-18 \%)$, GNE $(-11 \%)$ and ENP $(-5 \%)$. HI was also reduced by more than $11 \%$, although Bs did not show significant differences between elevated and ambient $\left[\mathrm{O}_{3}\right]$ treatments.

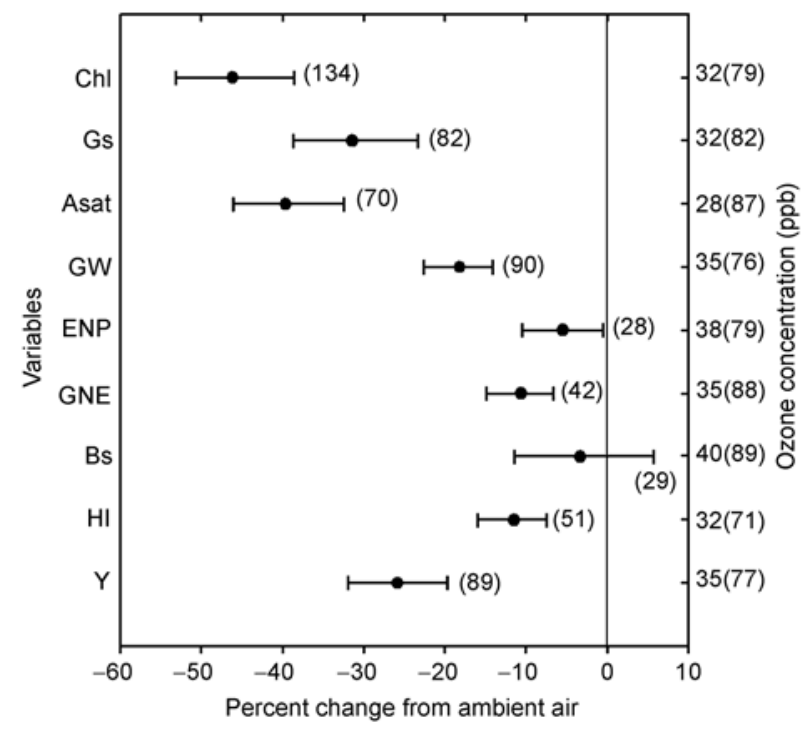

Figure 1 Effects of elevated $\left[\mathrm{O}_{3}\right]$ on wheat growth and yield components. Symbols represent the mean percent change at elevated $\left[\mathrm{O}_{3}\right]$ relative to ambient air and the bars show the $95 \%$ confidence intervals (Cls). The degrees of freedom are given in parentheses following bars. Average ambient and elevated $\left[\mathrm{O}_{3}\right]$ are given on the $y$-axis, respectively. Abbreviations for parameters are described as follows. Chl, chlorophyll content; Gs, stomatal conductance; Asat, light-saturated photosynthetic rate; GW individual grain weight; ENP, ears per plant; GNE, grains per ear; $\mathrm{Bs}$, above-ground biomass; $\mathrm{HI}$, harvest index; $\mathrm{Y}$, yield.

\subsection{Factors analysis}

(i) The effect of wheat types. All investigated variables showed no significant difference between winter wheat and spring wheat in the responses to elevated $\left[\mathrm{O}_{3}\right]$ (Figure 2), suggesting similar responses to elevated $\left[\mathrm{O}_{3}\right]$ despite different ecological types.

(ii) The effects of developmental stages and leaf ozone exposure duration. Here, we compare the responses of physiological character of leaves to elevated 


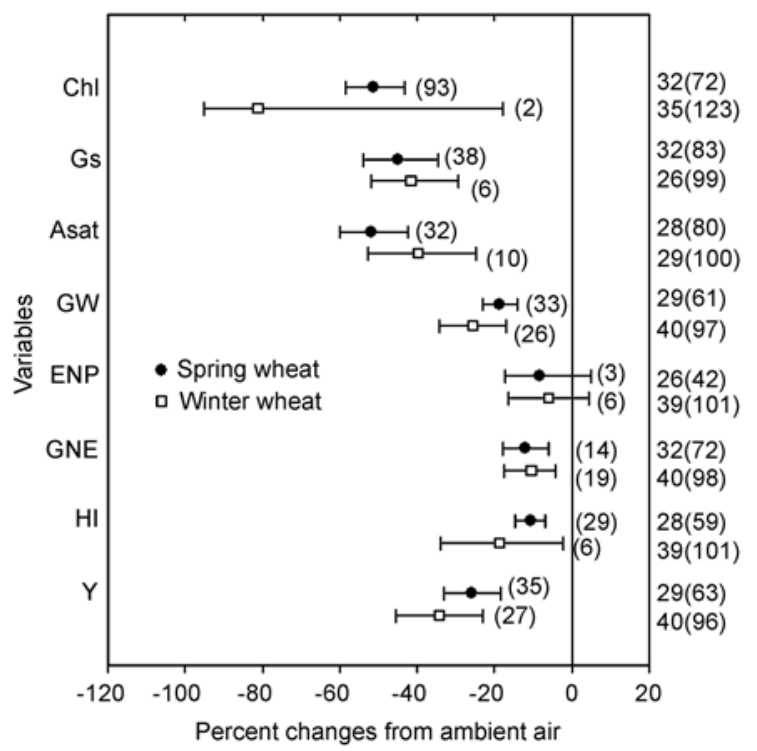

Figure 2 Effects of elevated $\left[\mathrm{O}_{3}\right]$ on spring wheat and winter wheat. Symbols represent the mean percent change at elevated $\left[\mathrm{O}_{3}\right]$ relative to ambient air and the bars show the 95\% confidence intervals (Cls). The degrees of freedom are given in parentheses following bars. Average ambient and elevated $\left[\mathrm{O}_{3}\right]$ are given on the $y$-axis, respectively. Abbreviations for parameters are described as follows. Chl, chlorophyll content; Gs, stomatal conductance; Asat, light-saturated photosynthetic rate; GW, individual grain weight; ENP, ears per plant; GNE, grains per ear; $\mathrm{HI}$, harvest index; $\mathrm{Y}$, yield.

$\left[\mathrm{O}_{3}\right]$ at different development stages (Figure 3). The detrimental impacts of $\mathrm{O}_{3}$ increased with developmental stages from young to old. From the mean effects, the data of Asat, Gs and Chl showed the least decrease during the vegetative growing stage and the largest during grain filling stage. In comparison with ambient $\left[\mathrm{O}_{3}\right]$, elevated $\left[\mathrm{O}_{3}\right]$ did not cause significant decreases in Asat, Gs and $\mathrm{Chl}$ at the vegetative stage, but the decreases at grain filling stage were significant larger than those at other stages.

There was a progressive decrease with increasing duration of leaf exposure to elevated $\left[\mathrm{O}_{3}\right]$ in Asat and Gs (Figure 4). Asat and Gs were decreased by $15 \%$ and $4 \%$ within 10 d of $\mathrm{O}_{3}$ exposure, respectively. But the decreases were $71 \%$ and $58 \%$, respectively, when $\mathrm{O}_{3}$ exposure duration was more than $20 \mathrm{~d}$.

(iii) The effect of $\left[\mathrm{O}_{3}\right]$. Except for ENP and Chl, the detrimental effect of $\mathrm{O}_{3}$ on leaf photosynthesis and $\mathrm{Bs}$ was linearly greater as the average daily $\left[\mathrm{O}_{3}\right]$ increased (Figure 5). Compared with ambient $\left[\mathrm{O}_{3}\right]$, the yield loss was $17 \%$ and $24 \%$ induced by averaged $\left[\mathrm{O}_{3}\right]$ of $51 \mathrm{ppb}$ and $75 \mathrm{ppb}$, respectively. Similar trend was also found in $\mathrm{GW}$. Asat appeared to be very sensitive to elevated $\left[\mathrm{O}_{3}\right]$.

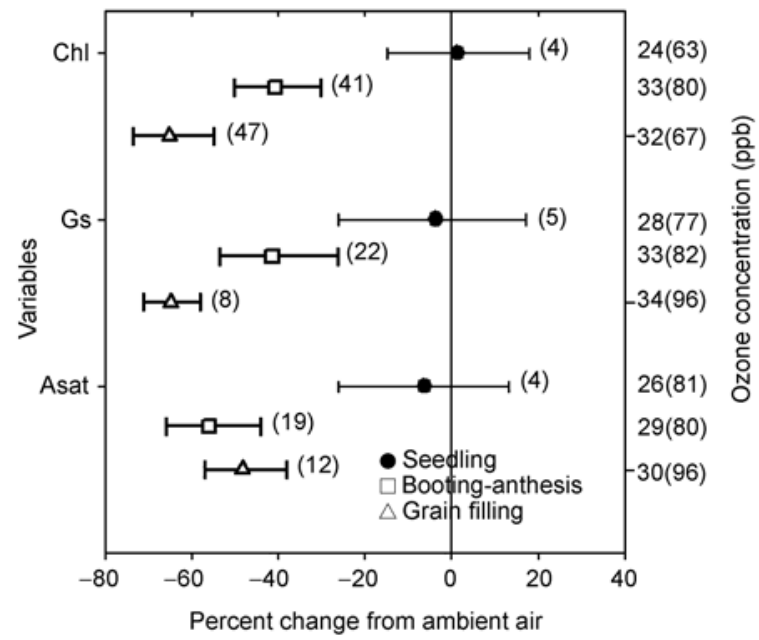

Figure 3 Response of wheat to elevated $\left[\mathrm{O}_{3}\right]$ at different developmental stages. Symbols represent the mean percent change at elevated $\left[\mathrm{O}_{3}\right]$ relative to ambient air and the bars show the $95 \%$ confidence intervals (Cls). The degrees of freedom are given in parentheses following bars. Average ambient and elevated $\left[\mathrm{O}_{3}\right]$ are given on the $y$-axis, respectively. Abbreviations for parameters are described as follows. Chl, chlorophyll content; Gs, stomatal conductance; Asat, light-saturated photosynthetic rate.

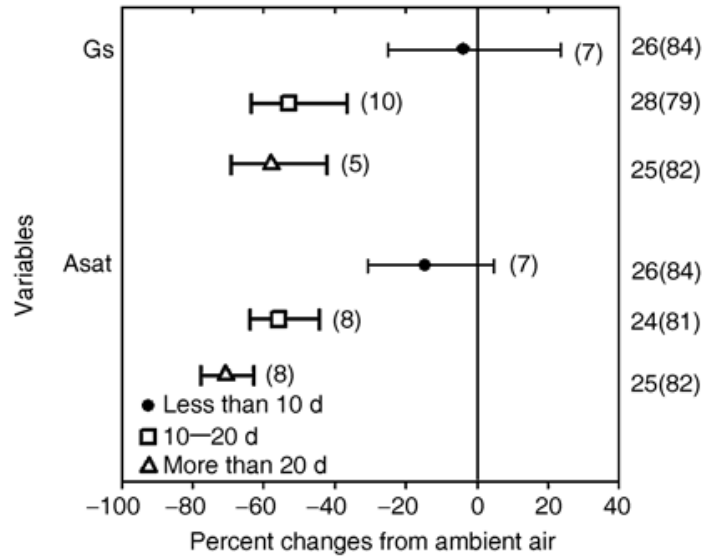

Figure 4 Response of wheat leaf to elevated $\left[\mathrm{O}_{3}\right]$ at different exposure duration. Symbols represent the mean percent change at elevated $\left[\mathrm{O}_{3}\right]$ relative to ambient air and the bars show the $95 \%$ confidence intervals $(\mathrm{Cls})$. The degrees of freedom are given in parentheses following bars. Average ambient and elevated $\left[\mathrm{O}_{3}\right]$ are given on the $y$-axis, respectively. Abbreviations for parameters are described as follows. Gs, stomatal conductance; Asat, light-saturated photosynthetic rate.

It was decreased by $33 \%$ at a mean of $49 \mathrm{ppb}$ of $\left[\mathrm{O}_{3}\right]$ and by more than $50 \%$ at $81 \mathrm{ppb}$, respectively. Moreover, lower than $60 \mathrm{ppb}$ of $\left[\mathrm{O}_{3}\right]$ significantly reduced all investigated variables with an exception of ENP and Gs (Figure 5).

(iv) The effect of elevated $\left[\mathrm{CO}_{2}\right]$. Based on the average effect, elevated $\left[\mathrm{CO}_{2}\right]$ significantly ameliorated or moderated the deleterious effects of $\mathrm{O}_{3}$ on photosynthesis and yield (Figure 6). There was no significant de- 


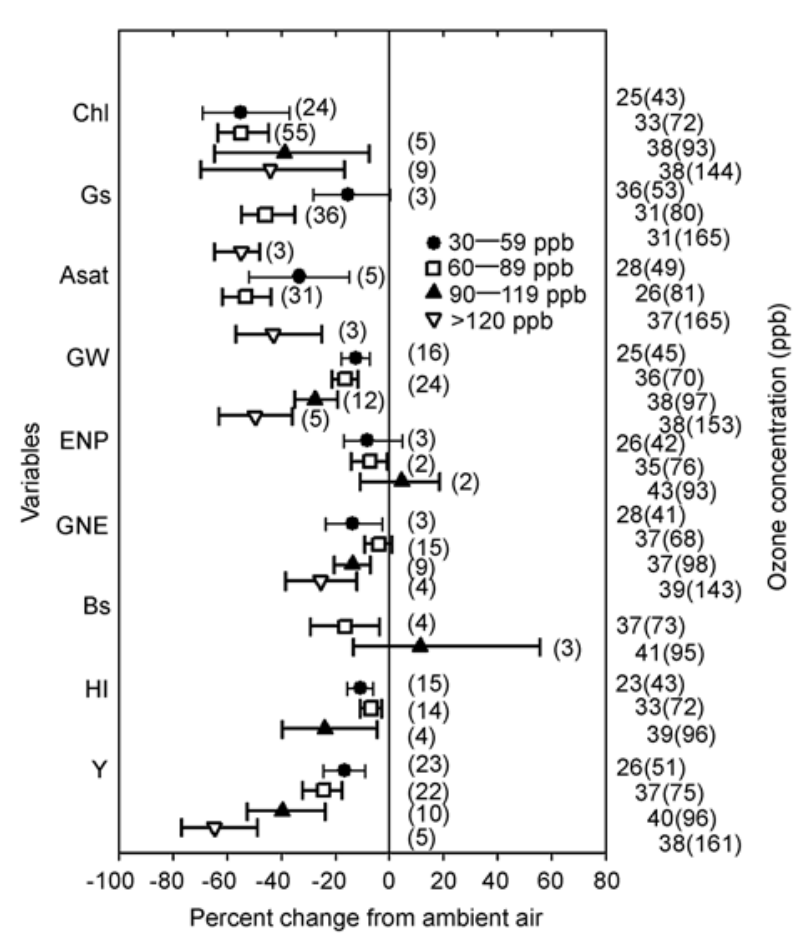

Figure 5 Effects of different concentrations of elevated $\left[\mathrm{O}_{3}\right]$ on wheat growth and yield components. Symbols represent the mean percent change at elevated $\left[\mathrm{O}_{3}\right]$ relative to ambient air and the bars show the $95 \%$ confidence intervals (Cls). The degrees of freedom are given in parentheses following bars. Average ambient and elevated $\left[\mathrm{O}_{3}\right]$ are given on the $y$-axis, respectively. Abbreviations for parameters are described as follows. Chl, chlorophyll content; Gs, stomatal conductance; Asat, light-saturated photosynthetic rate; $\mathrm{GW}$, individual grain weight; ENP, ears per plant; GNE, grains per ear; Bs, above-ground biomass; HI, harvest index; Y, yield.

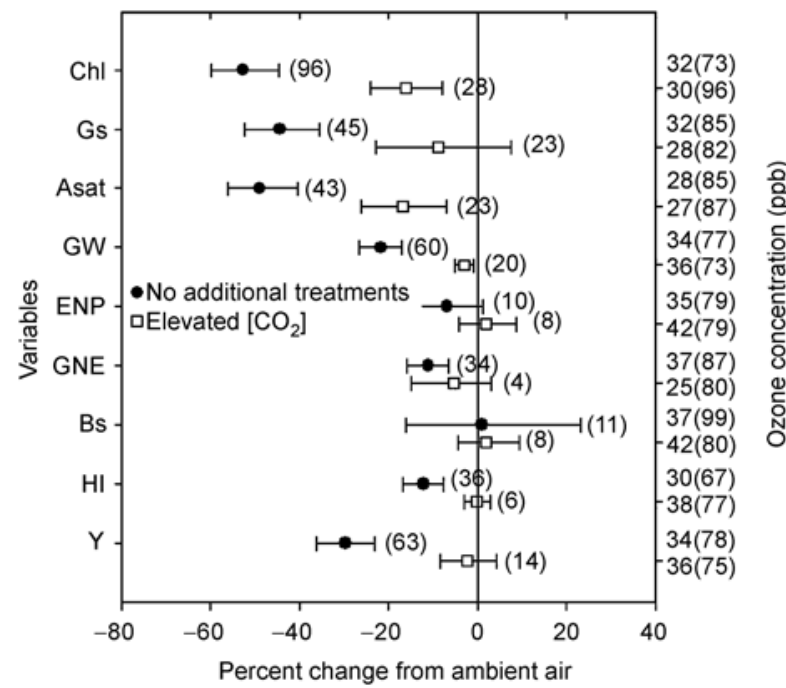

Figure 6 The interactive effect of elevated $\left[\mathrm{O}_{3}\right]$ on wheat with no additional treatments and with elevated $\left[\mathrm{CO}_{2}\right](>500 \mathrm{ppm})$. Symbols represent the mean percent change at elevated $\left[\mathrm{O}_{3}\right]$ relative to ambient air and the bars show the 95\% confidence intervals (Cls). The degrees of freedom are given in parentheses following bars. Average ambient and elevated $\left[\mathrm{O}_{3}\right]$ are given on the $y$-axis, respectively. Abbreviations for parameters are described as follows. Chl, chlorophyll content; Gs, stomatal conductance; Asat, light-saturated photosynthetic rate; GW, individual grain weight; ENP, ears per plant; GNE, grains per ear; Bs, above-ground biomass; HI, harvest index; $\mathrm{Y}$, yield. crease in grain yield, $\mathrm{HI}$ or GNE under combined elevation of $\left[\mathrm{CO}_{2}\right]$ and $\left[\mathrm{O}_{3}\right]$ (overlap with 0 ). For those studies with no additional treatments, elevated $\left[\mathrm{O}_{3}\right]$ decreased yield, GW and ENP by $30 \%, 22 \%$ and $11 \%$, respectively. However, the decreases were only $2 \%, 3 \%$ and $5 \%$ at elevated $\left[\mathrm{CO}_{2}\right]$, respectively, relative to ambient $\left[\mathrm{CO}_{2}\right]$. Besides, the reduction in Asat under a combination of elevated $\left[\mathrm{O}_{3}\right]$ and $\left[\mathrm{CO}_{2}\right]$ was $35 \%$ of that under ambient $\left[\mathrm{CO}_{2}\right]$ and elevated $\left[\mathrm{O}_{3}\right]$ (Figure 6). Similar trend was also found in Gs. Compared with the average $(-31 \%)$ across all studies (Figure 1), elevated $\left[\mathrm{O}_{3}\right]$ decreased $\mathrm{Gs}$ by $45 \%$ at ambient $\left[\mathrm{CO}_{2}\right]$, and no other additional treatments, but only by $9 \%$ at elevated $\left[\mathrm{CO}_{2}\right]$.

\section{Discussion}

With meta-analysis, we assessed quantitatively the effects of elevated $\left[\mathrm{O}_{3}\right]$ on physiological characters and grain yield of wheat. Results indicated that the average $\left[\mathrm{O}_{3}\right]$ of $77 \mathrm{ppb}$ decreased grain yield by $26 \%$, relative to current ambient $\left[\mathrm{O}_{3}\right]$, with a $95 \% \mathrm{CI}$ of $20 \%-32 \%$ in spite of variations in the response observed among studies. It can be inferred that wheat production in the near future may suffer serious losses if ambient $\left[\mathrm{O}_{3}\right]$ keeps rising. From our meta-analysis, the most important yield component responsible for grain yield reduction was the decrease of GW (18\%), although both ENP and GNE showed significant decreases at elevated $\left[\mathrm{O}_{3}\right]$. It is suggested that grain filling was damaged most by elevated $\left[\mathrm{O}_{3}\right]$ among the growth processes. Feng et al ${ }^{\left[{ }^{[2]}\right.}$ found elevated $\left[\mathrm{O}_{3}\right]$ significantly increased the number of empty grains in wheat with open-top chambers.

Like photosynthetic rate and photosynthetic pigment, the physiological variables of leaves were much more sensitive to $\left[\mathrm{O}_{3}\right]$ than yield. Within 135 measurements, averaged $\left[\mathrm{O}_{3}\right]$ of $79 \mathrm{ppb}$ decreased $\mathrm{Chl}$ by $46 \%$, suggesting that elevated $\left[\mathrm{O}_{3}\right]$ significantly accelerated leaf senescence. Early senescence of leaf by $\mathrm{O}_{3}$ was also found in other crops such as soybean ${ }^{[30]}$, potato ${ }^{[31]}$ and $\operatorname{corn}^{[32]}$. The significant decrease in Asat directly affected the fixation of carbohydrate and transformation to grain. The decrease in Gs indicated that less $\mathrm{O}_{3}$ entered into mesophyll cells, while the absorption of atmospheric $\mathrm{CO}_{2}$ for leaves was also decreased at the same time.

Our meta-analysis showed winter wheat and spring wheat had similar response to $\mathrm{O}_{3}$ in all investigated variables (Figure 2). From Figure 2, mean exposed $\left[\mathrm{O}_{3}\right]$ 
during winter wheat growth was reported markedly higher than that of spring wheat, which was caused by the difference in $\left[\mathrm{O}_{3}\right]$ calculation modes. Spring wheat was mostly studied in Europe, in which reported $\left[\mathrm{O}_{3}\right]$ was the average during whole developmental stages regardless of fumigation or not. However, winter wheat was usually fumigated after jointing stage, and $\left[\mathrm{O}_{3}\right]$ was calculated based on actual fumigation days, namely excluding days of no $\mathrm{O}_{3}$ fumigation.

From the analysis of published data on Asat, Gs and Chl, we found the most decrease occurred in grain filling stage across all developmental stages, in agreement with the results of a meta-analysis on soybean ${ }^{[19]}$. Pleijel et al. ${ }^{[17]}$ exposed field-grown spring wheat to the same $\mathrm{O}_{3}$ dose at different stages, and reported that $\mathrm{O}_{3}$ exposure at grain filling stage induced larger yield loss than that before anthesis. However, it can't be concluded that grain filling stage is the most sensitive to $\mathrm{O}_{3}$. In general, chronic $\mathrm{O}_{3}$ induced negative effects on plant physiological characters only if $\mathrm{O}_{3}$ flux in mesophyll reaches a much high level through accumulation effect, and further affects biomass and yield. This was confirmed by the results of Figure 4. Relative to ambient $\left[\mathrm{O}_{3}\right]$, Asat and Gs showed a significant decrease, only when wheat was exposed to elevated $\left[\mathrm{O}_{3}\right]$ of about $80 \mathrm{ppb}$ for more than 10 days, although the decreasing trends appeared within 10 days of fumigation (Figure 4).

It is well documented that elevated $\left[\mathrm{CO}_{2}\right]$ significantly decreased $\mathrm{Gs}^{[29,33]}$, which would decrease the $\mathrm{O}_{3}$ flux into intercellular spaces of the leaf. Consequently, it may be expected that the detrimental effects of $\mathrm{O}_{3}$ on plants would be less under stress conditions than under

1 Krupa S, McGrath M T, Andersen C P, et al. Ambient ozone and plant health. Plant Dis, 2001, 85: 4-12

2 Brasher E P, Fieldhouse D J, Sasser M. Ozone injury in potato variety trials. Plant Dis Rep, 1973, 57: 542-544

3 Heagle A S. Ozone and crop yield. Ann Rev Phytopathol, 1989, 27: $397-423$

4 Meehl G A, Stocker T F, Collins W D, et al. Global Climate Projections. Cambridge: Cambridge University Press, 2007

5 Fowler D, Cape J N, Coyle M, et al. Modelling photochemical oxidant formation, transport, deposition and exposure of terrestrial ecosystems. Environ Pollut, 1999, 100: 43-55

6 Ashmore M R. Assessing the future global impacts of ozone on vegetation. Plant Cell Environ, 2005, 28: 949-964

7 Karnosky D, Skelly J, Percy K, et al. Prospectives regarding 50 years of research on effects of tropospheric ozone air pollution on US for- non-stress conditions. This notion was supported by our analysis. From Asat and Chl, the decreases induced by elevated $\left[\mathrm{O}_{3}\right]$ were less at elevated $\left[\mathrm{CO}_{2}\right]$ than those at ambient $\left[\mathrm{CO}_{2}\right]$. Elevated $\left[\mathrm{CO}_{2}\right]$ also significantly ameliorated the large decrease in $\mathrm{Gs}$ induced by elevated $\left[\mathrm{O}_{3}\right]$ (Figure 6), implying that $\mathrm{O}_{3}$ flux into leaves was reduced significantly. Our result was consistent with Wittig et al. ${ }^{[20]}$ who investigated the effects of elevated $\left[\mathrm{CO}_{2}\right]$ on the response of $\mathrm{Gs}$ of trees to elevated $\left[\mathrm{O}_{3}\right]$. However, Morgan et al. ${ }^{[19]}$ indicated that elevated $\left[\mathrm{CO}_{2}\right]$ significantly increased the reduction in Gs induced by elevated $\left[\mathrm{O}_{3}\right]$, relative to ambient $\left[\mathrm{CO}_{2}\right]$. At the individual level, grain yield losses were partially or completely ameliorated by elevated $\left[\mathrm{CO}_{2}\right]$ in wheat. It was attributed to the improvement in synthesis of carbohydrates and transportation to grains and thus an increase in GW and ENP when wheat was planted at elevated $\left[\mathrm{CO}_{2}\right]^{[34]}$. Similar results were also found in the meta-analysis of soybean $^{[19]}$.

In summary, this study quantitatively investigated the effects of elevated $\left[\mathrm{O}_{3}\right]$ on yield formation and photosynthetic physiology by using a meta-analytic technique. Our meta-analysis indicated that the decrease in GW was the main cause of yield loss $(26 \%)$ induced by a mean $\left[\mathrm{O}_{3}\right]$ of $77 \mathrm{ppb}$. The response of physiological characters to $\mathrm{O}_{3}$ was more sensitive than that of yield. Elevated $\left[\mathrm{CO}_{2}\right]$ significantly alleviated the negative effects of elevated $\left[\mathrm{O}_{3}\right]$ on wheat. This study is a case of meta-analysis applied in the field of atmospheric environmental change. We hope domestic researchers could apply meta-analytic technique into ecological research, especially in the field of global climate change.

ests. Environ Pollut, 2007, 147: 489-506

8 Prather M, Gauss M, Berntsen T, et al. Fresh air in the 21 st century? Geophys Res Lett, 2003, 30(2): 1100

9 Long S P, Naidu S L. Effects of oxidants at the biochemical, cell and physiological levels. In: Treshow M, ed. Air Pollution and Plants. London: John Wiley, 2002. 69-88

10 Bai Y M, Guo J P, Wang C Y, et al. The reaction and sensitivity experiment of $\mathrm{O}_{3}$ on rice and winter wheat (in Chinese). Chin J Eco-Agr, 2002, 10(1): 13-16

11 Benton J, Fuhrer J, Gimeno B S, et al. An international cooperative programme indicates the widespread occurrence of ozone injury on crops. Agr Ecosyst Environ, 2000, 78: 19-30

12 Feng Z W, Jin M H, Zhang F Z, et al. Effects of ground-level ozone $\left(\mathrm{O}_{3}\right)$ pollution on the yields of rice and winter wheat in the Yangtze River Delta. J Environ Sci, 2003, 15: 360-362 
13 Fuhrer J, Booker F. Ecological issues related to ozone: agricultural issues. Environ Int, 2003, 29: 141-154

14 Mills G, Buse A, Gimeno B, et al. A synthesis of AOT40-based response functions and critical levels of ozone for agricultural and horticultural crops. Atmos Environ, 2007, 41: 2630-2643

15 Wang X K, Zheng Q W, Yao F F, et al. Assessing the impact of ambient ozone on growth and yield of a rice (Oryza sativa L.) and a wheat (Triticum aestivum L.) cultivar grown in the Yangtze Delta, China, using three rates of application of ethylenediurea (EDU). Environ Pollut, 2007, 148: 390-395

16 Wahid A, Maggs R, Shamsi S R A, et al. Air pollution and its impacts on wheat yield in the Pasistan Punjab. Environ Pollut, 1995, 88: $147-154$

17 Pleijel H, Danielsson H, Gelang J, et al. Growth stage dependence of the grain yield response to ozone in spring wheat (Triticum aestivum L.). Agr Ecosyst Environ, 1998, 70: 61-68

18 Meyer U, Kollner B, Willenbrink J, et al. Physiological changes on agricultural crops induced by different ambient ozone exposure regimes.1. Effects on photosynthesis and assimilate allocation in spring wheat. New Phytol, 1997, 136: 645-652

19 Morgan P B, Ainsworth E A, Long S P. How does elevated ozone impact soybean? A meta-analysis of photosynthesis, growth and yield. Plant Cell Environ, 2003, 26: 1317-1328

20 Wittig V E, Ainsworth E A, Long S P. To what extent do current and projected increases in surface ozone affect photosynthesis and stomatal conductance of trees? A meta-analytic review of the last 3 decades of experiments. Plant Cell Environ, 2007, 30: 1150-1162

21 Lei X D, Peng C H, Tian D L, et al. Meta-analysis and its application in global change research. Chin Sci Bull, 2006, 52(3): 289-302

22 Osenberg C W, Sarnelle O, Cooper S, et al. Resolving ecological questions through meta-analysis: Goals, metrics and models. Ecology, 1999, 80: 1105-1117

23 Peng S L, Tang X Y. Meta-analysis and its application in ecology (in
Chinese). J Ecol, 1998, 17(5): 74-79

24 Zheng F Y, Peng S L. Meta-analysis of prey relationships (in Chinese). Acta Ecol Sin, 1999, 19 (4): 448-452

25 Zheng F Y, Peng S L. Meta-analysis of the response of plant eco-physiological variables to doubled atmospheric $\mathrm{C}$ concentrations (in Chinese). Acta Botan Sin, 2001, 43 (11): 1101-1109

26 Curtis P S, Wang X. A meta-analysis of elevated $\mathrm{CO}_{2}$ effects on woody plant mass, form and physiology. Oecologia, 1998, 113: $299-313$

27 Ainsworth E A, Davey P A, Bernacchi C J, et al. A meta-analysis of elevated $\left[\mathrm{CO}_{2}\right]$ effects on soybean (Glycine max) physiology, growth and yield. Global Change Biol, 2002, 8: 695-709

28 Adams D C, Gurevitch J, Rosenberg M S. Resampling tests for meta-analysis of ecological data. Ecology, 1997, 78: 1277-1283

29 Feng Z Z, Yao F F, Chen Z, et al. Response of gas exchange and yield components of field-grown Triticum aestivum $\mathrm{L}$. to elevated ozone in China. Photosynthetica, 2007, 45: 441-446

30 Dermody O, Long S P, DeLucia E H. How does elevated $\mathrm{CO}_{2}$ or ozone affect the leaf-area index of soybean when applied independently? New Phytol, 2006, 169: 145-155

31 Donnelly A, Craigon J, Black C R, et al. Does elevated $\mathrm{CO}_{2}$ ameliorate the impact of $\mathrm{O}_{3}$ on chlorophyll content and photosynthesis in potato (Solanum tuberosum)? Physiol Plant, 2001, 111: 501-511

32 Leitao L, Bethenod O, Biolley J P. The impact of ozone on juvenile maize (Zea mays L.) plant photosynthesis: Effects on vegetative biomass, pigmentation, and carboxylases (PEPc and Rubisco). Plant Biol, 2007, 9: 478-488

33 Ainsworth E A, Rogers A. The response of photosynthesis and stomatal conductance to rising $\left[\mathrm{CO}_{2}\right]$ : mechanisms and environmental interactions. Plant Cell Environ, 2007, 30: 258-270

34 Wall G W, Garcia R L, Kimball B A, et al. Interactive effects of elevated carbon dioxide and drought on wheat. Agron J, 2006, 98 : $354-381$ 